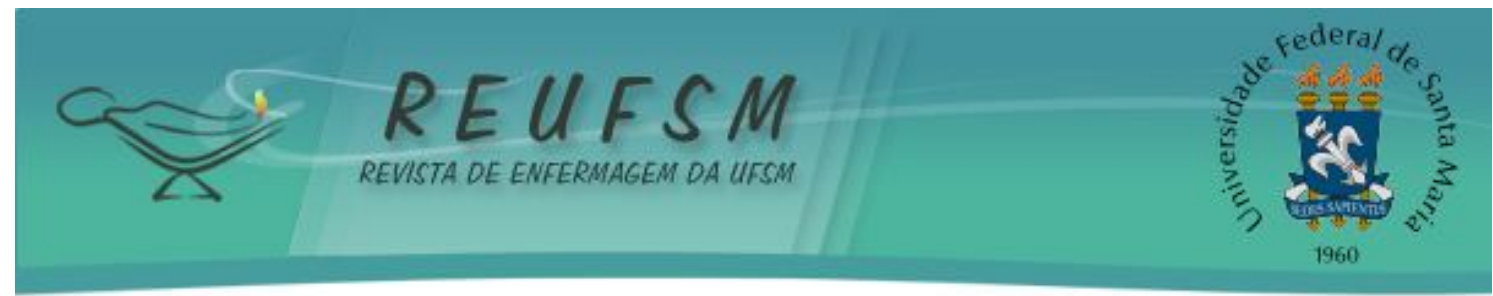

ARTIGO DE REVISÃO

\title{
CRENÇA RELIGIOSA E DOAÇÃO DE ÓRGÃOS E TECIDOS: REVISÃO INTEGRATIVA DA LITERATURA
}

\section{RELIGIOUS BELIEF AND DONATION OF ORGANS AND TISSUES: INTEGRATIVE REVIEW OF LITERAT URE}

\section{CREENCIAS RELIGIOSAS Y DONACIÓN DE ÓRGANOS Y TEJ IDOS: REVISIÓN INTEGRADORA DE LA LITERATURA}

\author{
Sílvia Ferrazzo ${ }^{1}$ \\ Mara Ambrosina de Oliveira Vargas ${ }^{2}$ \\ J oel Rolim Mancia ${ }^{3}$ \\ Flávia Regina Souza Ramos ${ }^{4}$
}

RESUMO: O estudo obj etivou analisar se a religião interfere na decisão do doador e/ ou da família de consentir com a doação de órgãos e com o processo de captação e transplante. Revisão integrativa da literatura realizada nas bases de dados SciELO, MEDLINE e LILACS, no período entre 1995 e 2010 que utilizou as palavras doação de órgãos, transplante de órgãos, ética, religião e crença religiosa, sendo selecionados 19 artigos. Concluiu-se que as convicções espirituais exercem influência na tomada de decisões. Nenhuma religião se posiciona de modo absoluto contrária à doação, mas a crença da morte relacionada à parada do coração e os rituais ligados ao corpo falecido limitam a possibilidade de adesão à doação e, posteriormente, ao transplante.

Descritores: Doação dirigida de tecido; Ética; Transplante de órgãos; Religião.

ABSTRACT: This study aims to analyzing whether religion interfere in the decision for donors and/ or their family to consent to both organ donation and the process of organ collection and transplantation. This integrating literature review has been carried out through searches in SciELO, MEDLINE and LILACS databases, from 1995 to 2010, using the following words: organ donation, organ transplantation, ethics, religion, and religious belief. Nineteen papers have been selected. We have concluded that spiritual beliefs have influence on decision-making. No religion has been completely contrary to donation, but the belief of death being related to heart failure, and the rituals associated with the dead body hinder the possibilities of adhering to donation and, ultimately, to transplantation.

Descriptors: Directed tissue donation; Ethics; Organ transplantation; Religion.

RESUMEN: El estudio objetivó analizar si la religión interfiera en la decisión del donante y/o de la familia de permitir la donación de órganos y con el proceso de captación y trasplante. Revisión integradora de la literatura realizada en las bases de datos SciELO, MEDLINE y LILACS, en el periodo entre 1995 y 2010, que utilizó las palabras donación de

\footnotetext{
1 Enfermeira. Graduação Enfermagem pela Universidade do Vale do Rio dos Sinos (UNISINOS). E-mail: silvia.ferrazzo@gmail.com.

${ }^{2}$ Enfermeira. Doutora em Enfermagem pela Universidade Federal de Santa Catarina (UFSC). Professora Adjunto Departamento Enfermagem da UFSC. Pesquisadora Grupo PRÁXIS - trabalho, cidadania, saúde e Enfermagem. E-mail: mara@ccs.ufsc.br.

${ }^{3}$ Enfermeiro. Doutor Enfermagem pela UFSC. Servidor Público Prefeitura Porto Alegre. Professor do Centro Universitário Metodista (IPA). Editor chefe da Revista Enfermagem em Foco. E-mail: joelmancia@uol.com.br.

${ }^{4}$ Enfermeira. Doutora em Filosofia em Enfermagem (UFSC). Professora do Departamento e Programa de Pósgraduação em Enfermagem (UFSC). Pesquisadora (CNPq) e Líder do Grupo de Pesquisa PRÁXIS. E-mail: flaviar@ccs.ufsc.br.
} 


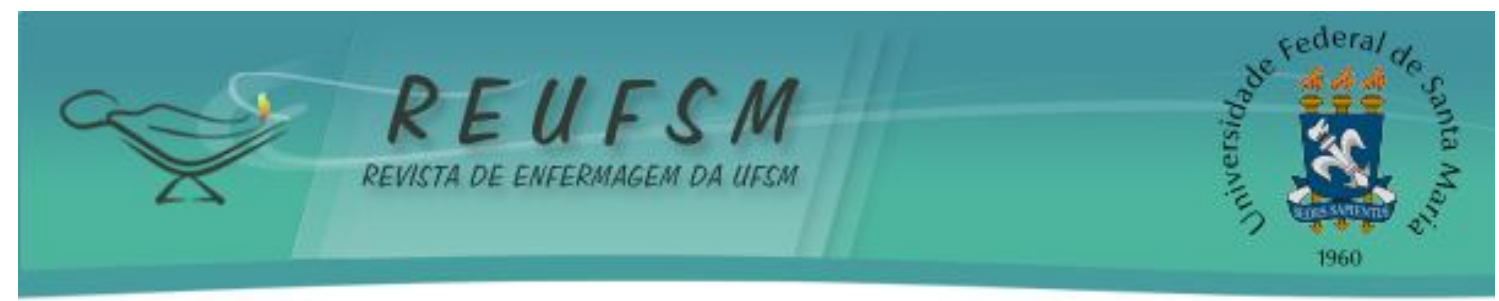

órganos, trasplante de órganos, ética, religión y creencia religiosa, siendo seleccionados 19 artículos. Por lo tanto se concluyó que las convicciones espirituales ej ercen influencia en la tomada de decisiones. Ninguna religión tiene una postura totalmente contraria a la donación, pero la creencia de la muerte relacionada al paro cardiaco y los rituales relacionados al cuerpo del difunto limitan la posibilidad de adhesión a la donación y posteriormente, al trasplante.

Descriptores: Donación directa de tejido; Ética; Trasplante de órganos; Religión.

\section{INTRODUÇÃO}

Doação de órgãos e tecidos é a expressão utilizada para a consolidação do procedimento de transplante. Entende-se como transplante a técnica cirúrgica substitutiva que consiste na retirada de órgão ou tecido humano pertencente a corpo vivo ou morto para utilização na própria pessoa ou em receptor, com fins terapêuticos, visando a substituir, no todo ou em parte, a função de outro da mesma natureza que não apresente funcionamento satisfatório à manutenção da vida. ${ }^{1}$

Doador potencial é todo paciente cuja terapêutica orientada para o cérebro foi avaliada como ineficaz ou cuja morte encefálica é iminente ou já ocorreu. ${ }^{2}$ A morte encefálica ocorre quando há parada circulatória definitiva e irreversível no encéfalo (cérebro e tronco cerebral), o que evolui em poucos minutos para a falência de outros órgãos vitais do organismo. ${ }^{3}$

No Brasil, a doação de órgãos é regulamentada pela LEI № 9434, de 04 de fevereiro de 1997, e pela LEI № 10211, de 23 de março de 2001, que reconhecem duas situações: a doação de órgãos de doador vivo, familiar até 40 grau de parentesco, mais frequentemente de rim, pois se trata de um órgão duplo; e a doação de órgãos e tecidos de doador falecido, que é determinada pela vontade dos familiares até $2^{\circ}$ grau de parentesco, mediante um termo de autorização de doação. ${ }^{4}$

O consentimento da família dos pacientes considerados doadores em potencial é atualmente a maior limitação no sucesso de transplantes de órgãos e tecidos. Esta realidade provocou grandes transformações e dilemas para a sociedade, e a família não está à parte dessa situação. Logo, mesmo com a existência de uma legislação própria, trata-se de um tema polêmico para os profissionais da área da saúde, os religiosos, os legistas, enfim, para a sociedade de modo geral. ${ }^{2}$

A legislação, que sempre é uma coerção do Estado sobre o indivíduo, pode estabelecer uma alteração no processo de captação de órgãos para fins de transplantes, contudo, nem sempre o resultado é o esperado. Muitas pessoas foram levadas a enfrentar um dilema de optar ou não por ser doador de órgãos, premidas pela legislação e pelo sentimento de ser ou não socialmente generosas, ainda que com conflitos de crenças; outras se sentiram coagidas socialmente por declarações equivocadas do tipo "quem não é doador também não pode ser receptor". E, no processo de tomada de decisão, o sistema de crenças de uma pessoa pode ter papel fundamental. Estas crenças, incluindo-se as religiosas, afetam a sua percepção e leitura do mundo, o conjunto das alternativas disponíveis e a seleção da ação que será realizada ou não. ${ }^{5}$

Considera-se, aqui, que religião comporta um "estado de ação" ou um sistema específico de práticas associado a uma denominação, seita ou outra forma de valor particular e que se define como um sistema de crenças e valores que uma pessoa pratica para exteriorizar sua espiritualidade. ${ }^{6}$

Ainda que os estudiosos que versam sobre a temática sejam de diferentes áreas do conhecimento, isto é, independentemente de serem da enfermagem, da medicina, do serviço social, do direito ou da ética, os conceitos e as correlações feitas entre a doação 


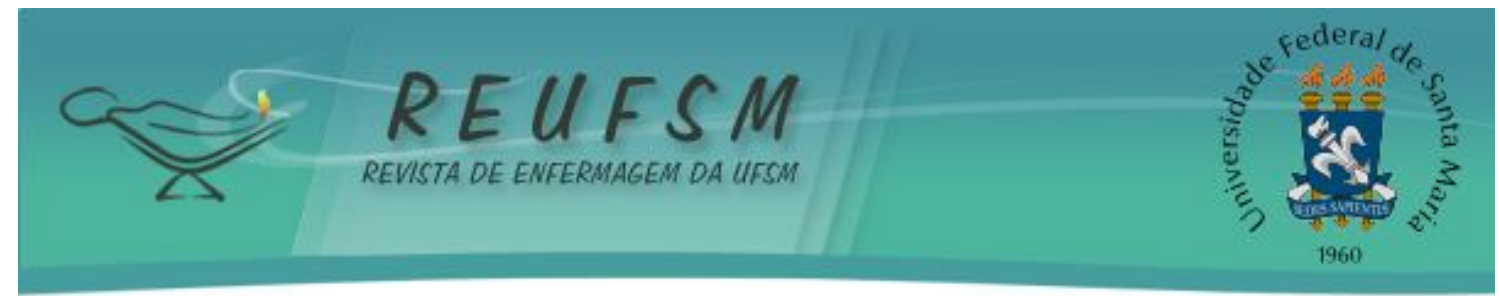

de órgãos e a cultura religiosa das pessoas se mostra relevante. A religião é um fator determinante na tomada de decisões das pessoas em qualquer área de suas vidas ${ }^{5}$; é, pois, base para a criação de normas e aspectos éticos e morais, bem como para a organização da convivência entre os seres humanos. ${ }^{7}$ Além disso, é fundamental o profissional enfermeiro adotar uma postura crítica e reflexiva nas discussões filosóficas e éticas quanto à sua responsabilidade no processo de manutenção da vida ou entendimento da morte e captação de órgãos. $^{8}$

Cientes de que as pessoas buscam apoio emocional nas religiões, antigas ou recentes, as quais trazem diferentes conceitos e decisões sobre a morte e como lidar com o corpo após o fato consumado, o estudo faz-se necessário, na medida em que permeia uma discussão complexa e multifacetada e capaz de interferir "poderosamente" no processo de decisão familiar de doar ou não órgãos e tecidos para transplante. O Sistema Único de Saúde disponibiliza recursos para execução deste tipo de procedimento, mas faltam doadores. Entender melhor esta insuficiência de doação permitirá avaliar se a enfermagem, como parte integrante e atuante da equipe de captação de órgãos e tecidos, pode contribuir para uma abordagem mais assertiva junto aos familiares de possíveis doadores, objetivando reduzir a espera dos doentes por um órgão. Nesta perspectiva, constituímos como objetivo: analisar se a religião interfere na decisão do doador e/ ou da família para o consentimento de doação de órgãos e o processo de captação e transplante.

\section{MÉTODO}

Revisão integrativa da literatura, realizada em dezembro de 2010, baseada em buscas nas bases de dados Literatura Latino-Americana e do Caribe em Ciências da Saúde (LILACS), Scientific Electronic (SciELO) e MEDLINE (PubMed), do período de 1995 a julho de 2010, com as palavras doação de órgãos e tecidos, ética, transplante de órgãos, religião e crença religiosa. Também foram utilizados os operadores boleanos or, and e not para haver melhor resultado da busca. Dos 135 artigos selecionados, foram revisados 19 artigos com diferentes delineamentos que focavam explicitamente a articulação entre a religião e o consentimento para doação, captação e transplante de órgãos.

\section{RESULTADOS}

No Quadro 1 apresentam-se os artigos selecionados de acordo com a fonte, tipo de estudo, área de conhecimento, objetivos e resultados.

\begin{tabular}{||l|l|l||}
\hline \hline Fonte & \multicolumn{1}{|c|}{$\begin{array}{c}\text { Tipo de Estudo/Área } \\
\text { Conhecimento/Objetivos }\end{array}$} & \multicolumn{1}{|c|}{ Resultados } \\
\hline $\begin{array}{l}\text { Morioka, } \\
1995 .{ }^{9}\end{array}$ & $\begin{array}{l}\text { Estudo de Revisão da Literatura } \\
\text { Área: Filosofia } \\
\text { Objetivo: explorar o conceito de } \\
\text { bioética, fatores culturais e o } \\
\text { entendimento de morte } \\
\text { encefálica, bem como a a a } \\
\text { aceitação de transplantes de } \\
\text { órgãos pela sociedade japonesa. }\end{array}$ & $\begin{array}{l}\text { Há barreira cultural contra o transplante, já que a } \\
\text { medicina moderna entrou em colisão com a visão } \\
\text { pe vida e morte no Japão. O corpo deve ser } \\
\text { alma torna-se infeliz no outro mundo. Acreditam } \\
\text { que pessoa morta pode comunicar-se com a } \\
\text { família enlutada psicológica e religiosamente, e a } \\
\text { tristeza da alma da pessoa morta pode afetar os } \\
\text { membros da família. }\end{array}$ \\
\hline \hline
\end{tabular}




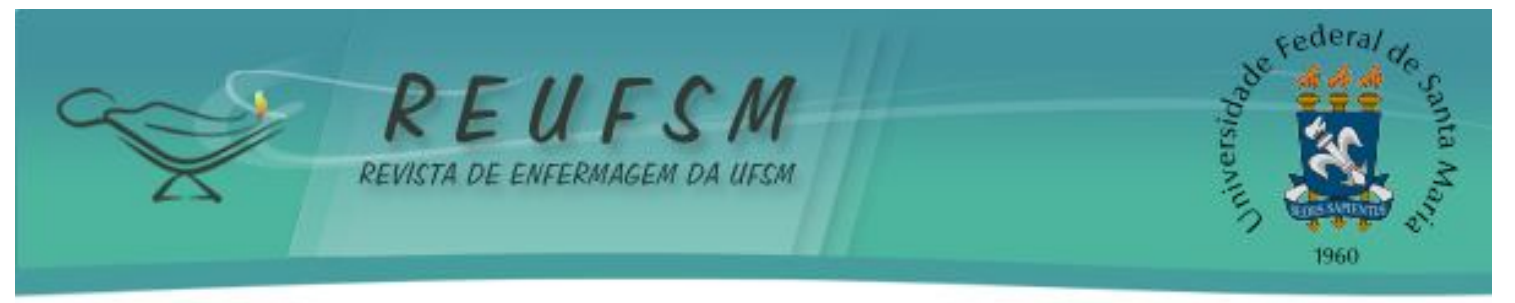

\begin{tabular}{|c|c|c|}
\hline $\begin{array}{l}\text { Knauth, } \\
\text { 1997. }^{10}\end{array}$ & $\begin{array}{l}\text { Estudo qualitativo, exploratório. } \\
\text { Realizou entrevistas com líderes } \\
\text { religiosos e fiéis. } \\
\text { Área: Bioética } \\
\text { Objetivo: avaliar a relação ou a } \\
\text { influência entre práticas e } \\
\text { crenças religiosas e adesão às } \\
\text { práticas médicas, como o } \\
\text { transplante de órgãos. }\end{array}$ & $\begin{array}{l}\text { Apesar de haver uma forte recorrência por parte } \\
\text { dos líderes religiosos em afirmarem-se favoráveis a } \\
\text { doações de sangue e órgãos, observaram-se } \\
\text { inúmeras contradições e mesmo exceções. Logo, } \\
\text { para a maioria das religiões estudadas, o } \\
\text { transplante de órgãos do doador falecido não é } \\
\text { visto de modo positivo, pois causaria uma } \\
\text { interferência negativa no desligamento do espírito } \\
\text { do corpo. Com relação ao momento da morte, a } \\
\text { maioria das religiões acredita que ela está } \\
\text { vinculada à parada do coração. Predomina a } \\
\text { crença de que o espírito permanece ligado ao } \\
\text { corpo por vários dias e de que a retirada de órgãos } \\
\text { seria traumática para o espírito. }\end{array}$ \\
\hline $\begin{array}{l}\text { Gualan- } \\
\text { dro, } \\
\text { Vilarino, } \\
\text { Soccol, } \\
\text { Almeida, } \\
\text { Neves, } \\
\text { 1997. }^{11}\end{array}$ & $\begin{array}{l}\text { Estudo qualitativo, exploratório } \\
\text { com representantes de crenças } \\
\text { religiosas. } \\
\text { Área: Medicina } \\
\text { Objetivos: verificar a influência } \\
\text { das religiões na anuência da lei } \\
\text { que tornava todos os brasileiros } \\
\text { doadores, a menos que se } \\
\text { manifestassem contrários em } \\
\text { documentos oficiais; a aceitação } \\
\text { do conceito de morte encefálica } \\
\text { e na liberdade de escolha; e o } \\
\text { impacto da religião na aceitação } \\
\text { dos transplantes. }\end{array}$ & $\begin{array}{l}\text { As religiões mostram-se a favor do transplante de } \\
\text { órgãos com algumas restrições. Dentre estas, os } \\
\text { Israelitas não permitem o transplante de coração } \\
\text { porque este ainda é um sinal de vida; é permitida } \\
\text { a retirada dos demais órgãos imediatamente após a } \\
\text { morte. As Testemunhas de Jeová não permitem o } \\
\text { transplante caso haja necessidade de transfusão } \\
\text { sanguínea. Na igreja Católica, o padre destaca o } \\
\text { medo do comércio de órgãos. A Adventista do } \\
\text { Sétimo Dia posiciona-se contrária à lei por } \\
\text { interferir na liberdade. Prevalece a desinformação } \\
\text { da nova lei e que a religião não exerce influência } \\
\text { significativa nos fiéis sobre transplante e a lei } \\
\text { sancionada. }\end{array}$ \\
\hline $\begin{array}{l}\text { Randha- } \\
\text { wa, } \\
\text { 1998. }{ }^{12}\end{array}$ & $\begin{array}{l}\text { Estudo qualitativo, exploratório, } \\
\text { com a população asiática que } \\
\text { vive em Luton, no Reino Unido. } \\
\text { Área: Medicina } \\
\text { Objetivo: analisar a influência } \\
\text { religião, entre outras coisas, } \\
\text { sobre o alcance e o sentido de } \\
\text { atitudes públicas em relação à } \\
\text { doação de órgãos. }\end{array}$ & $\begin{array}{l}\text { As religiões não fazem objeções à doação de } \\
\text { órgãos. Não há nada nas escrituras hindus que } \\
\text { indique que os órgãos não podem ser doados. No } \\
\text { Sikhismo e Budismo, não há proibição ao } \\
\text { transplante de órgãos. Na crença cristã, doação de } \\
\text { órgãos é aceito se o consentimento prévio foi } \\
\text { obtido do doador em vida e/ ou doação de parentes } \\
\text { próximos. Na população asiática, cultura e religião } \\
\text { têm papel menos proibitivo na opção da doação de } \\
\text { órgãos que anteriormente sugerido. }\end{array}$ \\
\hline $\begin{array}{l}\text { Pessini, } \\
\text { 1999. }{ }^{13}\end{array}$ & $\begin{array}{l}\text { Estudo de revisão da literatura. } \\
\text { Área: Bioética } \\
\text { Objetivo: abordar aspectos da } \\
\text { polêmica sobre a eutanásia e } \\
\text { transplante entre as quatro } \\
\text { maiores religiões mundiais: } \\
\text { budismo, islamismo, judaísmo e } \\
\text { cristianismo. }\end{array}$ & $\begin{array}{l}\text { No budismo, remover um órgão de um cadáver é } \\
\text { visto como perturbador da unidade corpo e } \\
\text { espírito. Budistas japoneses acreditam que a } \\
\text { diminuição gradual do calor corporal deve ser } \\
\text { sentida no processo de morrer e que apressar isso } \\
\text { não é um fim de vida esperado. No Islã, o corpo é } \\
\text { inviolável e sagrado durante a vida e depois da } \\
\text { morte. A questão de quando precisamente termina } \\
\text { a vida humana é discutida entre os bioeticistas } \\
\text { judeus contemporâneos; rabinos conservadores não }\end{array}$ \\
\hline
\end{tabular}




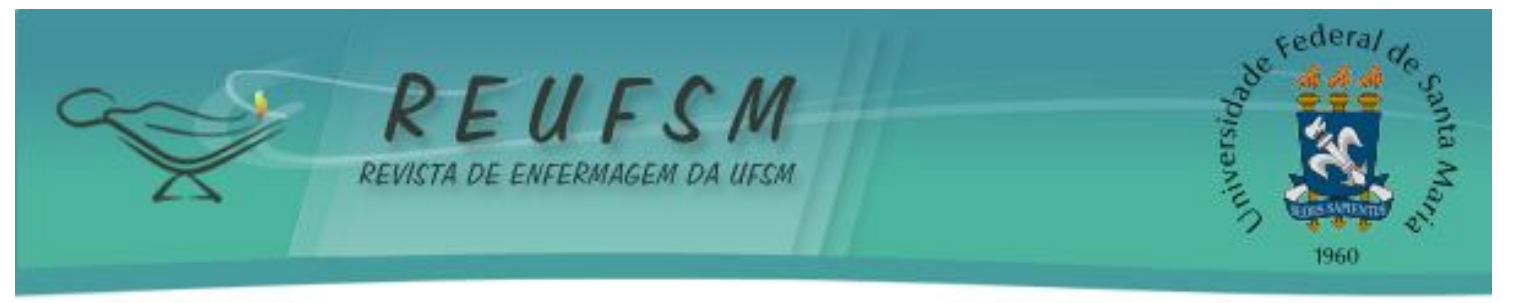

\begin{tabular}{|c|c|c|}
\hline & & $\begin{array}{l}\text { aceitam que a morte encefálica seja critério de } \\
\text { morte. No cristianismo, não há obrigatoriedade } \\
\text { quanto à preservação do corpo após a morte. }\end{array}$ \\
\hline $\begin{array}{l}\text { Lam, } \\
\text { Mccullou } \\
\text { gh, } \\
2000 .\end{array}$ & $\begin{array}{l}\text { Estudo qualitativo, exploratório, } \\
\text { por meio de aplicação de } \\
\text { questionário a participantes da } \\
\text { igreja Chinesa-Americana, no } \\
\text { Texas. } \\
\text { Área: Medicina } \\
\text { Objetivo: avaliar as razões } \\
\text { religiosas e culturais que fazia } \\
\text { os Chineses que viviam nos } \\
\text { Estados Unidos serem menos } \\
\text { dispostos a doar órgãos que } \\
\text { populações de outras origens. }\end{array}$ & $\begin{array}{l}\text { Alguns budistas alegam que não há nada } \\
\text { intrinsecamente sagrado sobre o corpo e que doar } \\
\text { órgãos é um grande ato de compaixão. Outros } \\
\text { acreditam que o budismo exige uma morte pacífica } \\
\text { e que a remoção de órgãos pode acarretar grande } \\
\text { dor ao espírito, o que interfere para um } \\
\text { renascimento bem-sucedido. No Taoísmo, partes } \\
\text { do corpo humano têm uma relação com a } \\
\text { natureza. Corpo e natureza são cuidadosamente } \\
\text { alinhados, e a remoção de órgãos pode perturbar } \\
\text { este equilíbrio. As pessoas que menos comparecem } \\
\text { às práticas religiosas aceitam mais a doação. }\end{array}$ \\
\hline $\begin{array}{l}\text { Dixon, } \\
\text { Abbey, } \\
2000.15\end{array}$ & $\begin{array}{l}\text { Estudo de caso com dois } \\
\text { participantes que aceitaram } \\
\text { doar um de seus rins em vida } \\
\text { para pessoas sem parentesco - } \\
\text { um homem e uma mulher que } \\
\text { pertenciam à igreja Evangélica. } \\
\text { Área: Psiquiatria } \\
\text { Objetivo: relacionar o altruísmo } \\
\text { religioso e a doação de órgãos. }\end{array}$ & $\begin{array}{l}\text { A primeira relatou que o beneficiário era um } \\
\text { membro da igreja e que, após aprender sobre a } \\
\text { insuficiência renal crônica, os efeitos da diálise } \\
\text { sobre a saúde física e psíquica e a possibilidade de } \\
\text { transplante como opção de tratamento definitivo, } \\
\text { resolveu manifestar de forma proativa seu } \\
\text { altruísmo religioso. Quando jovem, interpretava } \\
\text { sua fé católica como exigência de autopunição por } \\
\text { mau comportamento. O segundo explicou que sua } \\
\text { decisão para doar um rim evoluiu rapidamente e } \\
\text { ficou alinhada com suas convicções espirituais. }\end{array}$ \\
\hline $\begin{array}{l}\text { Bendas- } \\
\text { soli, } \\
\text { 2001. } 16\end{array}$ & $\begin{array}{l}\text { Estudo qualitativo, exploratório, } \\
\text { abrangendo três estudos } \\
\text { interdependentes, totalizando } \\
192 \text { estudantes de uma } \\
\text { universidade de São Paulo. } \\
\text { Área: Psicologia } \\
\text { Objetivo: levantar as principais } \\
\text { razões que levam estudantes } \\
\text { universitários a doar seus órgãos } \\
\text { para transplante e as relações } \\
\text { entre doação de órgãos, o medo } \\
\text { da morte a religião. }\end{array}$ & $\begin{array}{l}\text { O medo da morte e a religião estão associados à } \\
\text { não-doação de órgãos. Os três estudos foram } \\
\text { praticamente unânimes em apontar a fraca relação } \\
\text { entre doação de órgãos e religião. A religião, } \\
\text { independentemente do grau de envolvimento da } \\
\text { pessoa, foi citada como a menos importante para } \\
\text { justificar as opções dos entrevistados. No } \\
\text { ambiente universitário, o referencial religioso cede } \\
\text { espaço em detrimento de concepções mais } \\
\text { "objetivas", tais como ajudar as pessoas, } \\
\text { continuar a vida delas e aproveitar racionalmente } \\
\text { o alcance e a finalidade prática de uma tecnologia } \\
\text { moral e cientificamente legitimada: os } \\
\text { transplantes de órgãos. }\end{array}$ \\
\hline $\begin{array}{l}\text { Sadala, } \\
2001 .{ }^{17}\end{array}$ & $\begin{array}{l}\text { Estudo fenomenológico, } \\
\text { realizado com } 18 \text { familiares de } \\
\text { doadores na cidade de São } \\
\text { Paulo. } \\
\text { Área: Enfermagem } \\
\begin{array}{l}\text { Objetivo: investigar } \\
\text { perspectiva de familiares de }\end{array}\end{array}$ & $\begin{array}{l}\text { A religião apareceu para alguns como aconselhador } \\
\text { no momento da tomada de decisão. A família } \\
\text { busca um significado mais transcendental para } \\
\text { justificar seu consentimento. É mais tranquilo doar } \\
\text { os órgãos quando os familiares têm na religião } \\
\text { explicações e apoio para decidir. Para outros, no } \\
\text { ato de doar, há uma conotação mística e religiosa } \\
\text { com o valor de conceder a vida novamente a }\end{array}$ \\
\hline
\end{tabular}




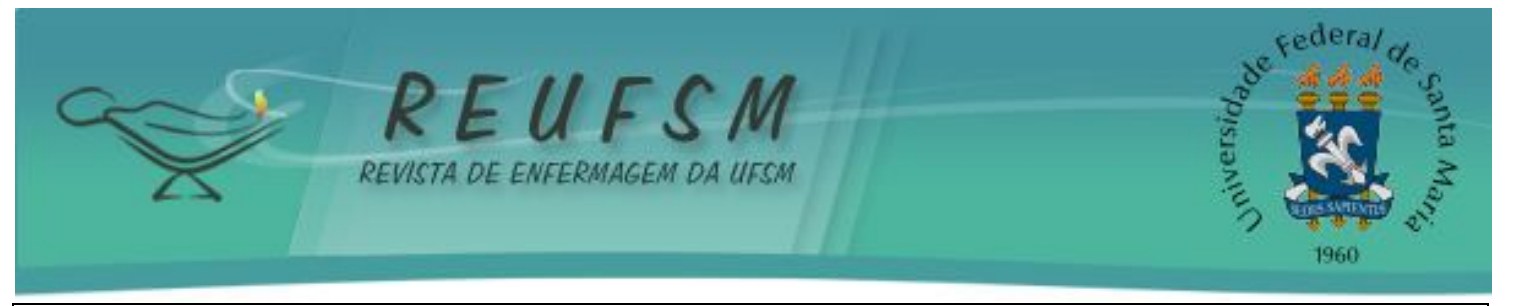

\begin{tabular}{|c|c|c|}
\hline & $\begin{array}{lcc}\text { doadores de órgãos } & \text { na } \\
\text { experiência de consentir } & \text { na } \\
\text { doação para transplante. } & \end{array}$ & $\begin{array}{l}\text { alguém. Nas divergências de posições filosóficas e } \\
\text { religiosas, a decisão de doar gera conflitos no } \\
\text { núcleo familiar. }\end{array}$ \\
\hline $\begin{array}{l}\text { West, } \\
\text { Burr, } \\
\text { 2002. }\end{array}$ & $\begin{array}{l}\text { Estudo de revisão da literatura } \\
\text { Área: Enfermagem } \\
\text { Objetivo: determinar os fatores } \\
\text { que influenciam a negação ao } \\
\text { consentimento para doação de } \\
\text { órgãos por parte de familiares } \\
\text { de potenciais doadores. }\end{array}$ & $\begin{array}{l}\text { Há conhecimento insuficiente sobre morte } \\
\text { encefálica, o tempo para pedido da doação junto à } \\
\text { família e as crenças culturais, incluindo as } \\
\text { religiosas. Evidenciada a crença no conceito de } \\
\text { sepultamento do corpo inteiro para manter boa } \\
\text { relação com os mortos e o medo da mutilação, o } \\
\text { que comprometeria rituais de sepultamento. }\end{array}$ \\
\hline $\begin{array}{l}\text { Howitt, } \\
2003 .{ }^{19}\end{array}$ & $\begin{array}{l}\text { Estudo de revisão da literatura } \\
\text { (folhetos informativos). } \\
\text { Área: Medicina } \\
\text { Objetivo: esclarecer a } \\
\text { importância do transplante e os } \\
\text { testes conclusivos de morte } \\
\text { encefálica. Salientar que o } \\
\text { consentimento para retirada de } \\
\text { órgãos para transplante é da } \\
\text { família do doador e a } \\
\text { importância de discutir o tema } \\
\text { no convívio familiar. Ressaltar } \\
\text { que a retirada dos órgãos é } \\
\text { realizada com cuidado e } \\
\text { respeito e que a família pode } \\
\text { ver o corpo na companhia de um } \\
\text { capelão ou líder religioso. }\end{array}$ & $\begin{array}{l}\text { Em algumas tradições Budistas, a morte é definida } \\
\text { por critérios diferentes daqueles da medicina } \\
\text { ocidental. O Cristianismo incentiva a doação, } \\
\text { destacando que o Senhor doou sua própria vida. A } \\
\text { Igreja Metodista do Reino Unido apóia a doação e } \\
\text { transplante em determinadas circunstâncias. Há } \\
\text { referências que as escrituras Hindus apóiam a } \\
\text { doação. No Islã, violar o corpo é proibido, exceto } \\
\text { para salvar vidas. Estudiosos muçulmanos declaram } \\
\text { que a doação é um ato mérito e pode ser uma } \\
\text { obrigação. No Judaísmo, a doação é incentivada } \\
\text { desde que a retirada de órgãos ocorra após a } \\
\text { morte. Na filosofia Sikh, um dos ensinamentos é } \\
\text { colocar os outros antes de si; a vida continua após } \\
\text { a morte na alma, e não no corpo, e é importante } \\
\text { doar. }\end{array}$ \\
\hline $\begin{array}{l}\text { Akrami, } \\
\text { Osati, } \\
\text { Zahedi, } \\
\text { Raza, } \\
\text { Brain, } \\
2004 .{ }^{20}\end{array}$ & $\begin{array}{l}\text { Estudo de revisão da literatura } \\
\text { Área: Medicina } \\
\text { Objetivo: apresentar os avanços } \\
\text { recentes na legislação iraniana } \\
\text { acerca da ética na definição de } \\
\text { morte encefálica e transplante } \\
\text { de órgãos. }\end{array}$ & $\begin{array}{l}\text { O Alcorão menciona que qualquer medicação, } \\
\text { tratamento e prevenção considerados para manter } \\
\text { a saúde da humanidade é aceito e recomendado. O } \\
\text { Islã não proíbe a doação e o transplante. Em 1999, } \\
\text { foi aprovada a implantação de critérios para } \\
\text { determinar a morte encefálica e possibilidade de } \\
\text { consentimento por parte da família para doação. } \\
\text { Destaca-se a influência social, cultural e religiosa } \\
\text { na prática médica; mesmo com a legislação } \\
\text { vigente, a taxa de transplantes de doadores } \\
\text { falecidos permaneceu baixa devido ao respeito e } \\
\text { medo de mutilação do corpo que existe na cultura } \\
\text { islâmica. }\end{array}$ \\
\hline $\begin{array}{l}\text { Blok, } \\
2006.21\end{array}$ & $\begin{array}{l}\text { Estudo de revisão da literatura } \\
\text { Área: Medicina } \\
\text { Objetivo: discutir a relação } \\
\text { entre fatores éticos, culturais e }\end{array}$ & $\begin{array}{l}\text { As atitudes, crenças e opiniões das pessoas, } \\
\text { especialmente as de origem religiosa ou cultural } \\
\text { específicas, não se alteraram significativamente na } \\
\text { última década. Fatores culturais e religiosos } \\
\text { impactam negativamente nas taxas de doadores, e } \\
\text { compreender melhor o significado destes fatores }\end{array}$ \\
\hline
\end{tabular}




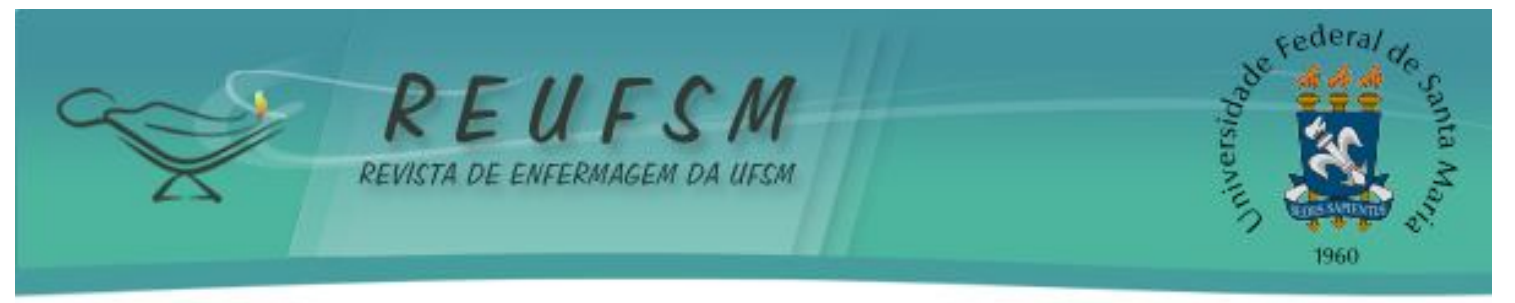

\begin{tabular}{|c|c|c|}
\hline & $\begin{array}{l}\text { religiosos e a vontade e a } \\
\text { decisão real de doar órgãos. }\end{array}$ & $\begin{array}{l}\text { nos momentos de doença e morte contribui para } \\
\text { criar métodos e intervenções mais eficazes na } \\
\text { captação de órgãos. }\end{array}$ \\
\hline $\begin{array}{l}\text { Velez, } \\
2007.22\end{array}$ & $\begin{array}{l}\text { Estudo qualitativo do tipo } \\
\text { narrativo. Coletado entre } \\
\text { parentes de pacientes. } \\
\text { Área: Enfermagem } \\
\text { Objetivo: captar a significância } \\
\text { do aspecto sociocultural do ato } \\
\text { de doar a partir de uma } \\
\text { perspectiva antropológica. }\end{array}$ & $\begin{array}{l}\text { A doação de órgãos é um ato social, tendo como } \\
\text { fatores determinantes para a tomada de decisão a } \\
\text { idade, sexo, religião e treinamento de pessoal. } \\
\text { Nenhuma religião proíbe a doação; apenas algumas } \\
\text { derivadas da doutrina budista, o xintoísmo, } \\
\text { taoísmo e movimento zen não permitem remover } \\
\text { as vísceras, não por proibir a doação, mas porque } \\
\text { seus rituais antes de morrer impedem essa prática. }\end{array}$ \\
\hline $\begin{array}{l}\text { Bruzzon } \\
\text { e, } \\
2008 .^{23}\end{array}$ & $\begin{array}{l}\text { Estudo de revisão da literatura } \\
\text { com publicações de estudiosos } \\
\text { de ética e religião, membros de } \\
\text { universidades americanas e } \\
\text { declarações de autoridades } \\
\text { religiosas dadas em congressos e } \\
\text { encontros destinados a tratar do } \\
\text { assunto doação de órgãos. } \\
\text { Área: Bioética } \\
\text { Objetivo: apresentar a relação } \\
\text { entre a religião e transplante de } \\
\text { órgãos. }\end{array}$ & $\begin{array}{l}\text { Nenhuma religião proíbe formalmente doar ou } \\
\text { receber órgãos de doadores vivos ou falecidos. } \\
\text { Alguns Ulemás muçulmanos da Ásia e Muftis se } \\
\text { opõem à doação em vida ou morte por considerar o } \\
\text { corpo sob "tutela de Deus", sendo inviolável após } \\
\text { sua morte. O Catolicismo é defensor e incentivador } \\
\text { da doação como um ato de amor; devido à sagrada } \\
\text { natureza da vida humana, é contra a doação de } \\
\text { doadores anencéfalos ou após a eutanásia ativa. } \\
\text { No Islamismo, o ser humano não é proprietário de } \\
\text { uma parte ou totalidade de seu corpo, e seus } \\
\text { órgãos não devem ser negociados, mas doados. }\end{array}$ \\
\hline $\begin{array}{l}\text { Solar, } \\
\text { Ovalle, } \\
\text { Simian, } \\
\text { Escobar, } \\
\text { Beca, } \\
\text { 2008. }{ }^{24}\end{array}$ & $\begin{array}{l}\text { Estudo de revisão da literatura } \\
\text { Área: Medicina } \\
\text { Objetivo: levantar os fatores } \\
\text { que influenciam as atitudes das } \\
\text { pessoas perante a decisão de } \\
\text { doar órgãos. }\end{array}$ & $\begin{array}{l}\text { Ressalta pesquisa realizada com católicos } \\
\text { espanhóis. Apenas 25\% mostraram conhecer a } \\
\text { posição favorável do Catolicismo em relação à } \\
\text { doação de órgãos; apesar disto, } 63 \% \text { dos fiéis } \\
\text { mostraram-se favoráveis à doação. Os católicos } \\
\text { considerados praticantes assumem uma posição de } \\
\text { maior aceitação em doar ou receber órgãos. Entre } \\
\text { os chilenos, a religião é motivo de negação em } 10 \% \\
\text { dos casos de potenciais doadores. }\end{array}$ \\
\hline $\begin{array}{l}\text { Rios, } \\
\text { Alarcón, } \\
\text { Sanches, } \\
\text { Jarvis, } \\
\text { Garcia, } \\
\text { Parrilla, } \\
\text { Ramirez, } \\
\text { 2008. }^{25}\end{array}$ & $\begin{array}{l}\text { Estudo quantitativo, } \\
\text { exploratório. Aplicado } \\
\text { questionário para comunidade } \\
\text { regional autônoma de Múrcia, } \\
\text { sudoeste da Espanha. A idéia é } \\
\text { que, na maioria dos países } \\
\text { ocidentais desenvolvidos, há } \\
\text { uma tendência para a doação } \\
\text { renal em vida. }\end{array}$ & $\begin{array}{l}\text { 90\% mostraram-se favoráveis à doação renal em } \\
\text { vida, } 9 \% \text { contra e } 1 \% \text { não estava certo de sua } \\
\text { opinião. Dentre as variáveis consideradas, estavam } \\
\text { a possibilidade de o receptor ser ou não um } \\
\text { membro da família e a religião do possível doador, } \\
\text { bem como o conhecimento sobre o que sua crença } \\
\text { religiosa orienta. A religião não aparece associada } \\
\text { como fator decisivo para doação de rim em vida, } \\
\text { conforme afirmam católicos e protestantes } \\
\text { anglicanos. Mas, existe uma associação }\end{array}$ \\
\hline
\end{tabular}




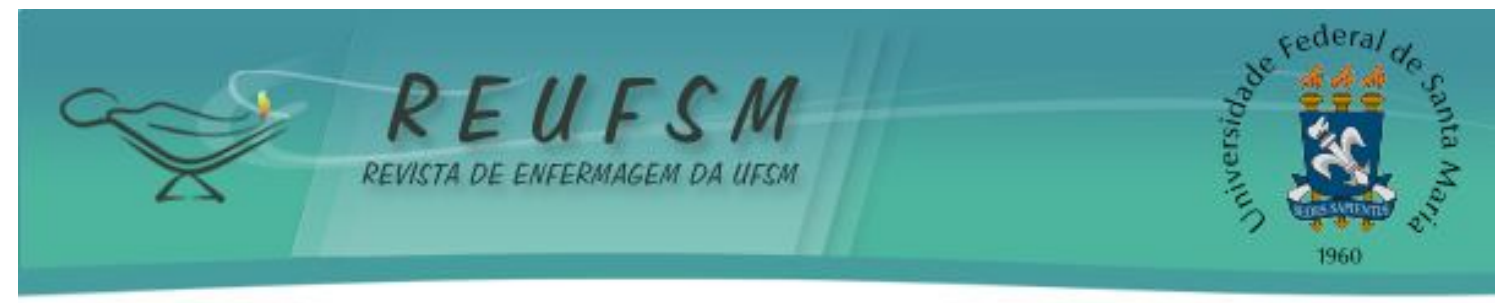

\begin{tabular}{|c|c|c|}
\hline & $\begin{array}{l}\text { Area: Medicina } \\
\text { Objetivo: analisar a atitude de } \\
\text { uma população de origem } \\
\text { britânica e irlandesa no sudoeste } \\
\text { da Espanha no sentido de } \\
\text { doação de rim em vida. }\end{array}$ & $\begin{array}{l}\text { significativa para saber se sua religião é a favor ou } \\
\text { não da doação e transplante, sendo que apenas } \\
30 \% \text { dos entrevistados sabem que sua religião } \\
\text { possui uma atitude favorável em relação à doação. }\end{array}$ \\
\hline $\begin{array}{l}\text { Moraes, } \\
\text { Massaro- } \\
\text { llo, } \\
2009 .{ }^{26}\end{array}$ & $\begin{array}{l}\text { Estudo qualitativo, exploratório. } \\
\text { Entrevistados oito familiares que } \\
\text { recusaram a doação em uma } \\
\text { Organização de Procura de } \\
\text { Órgãos do município de São } \\
\text { Paulo. } \\
\text { Área: Enfermagem } \\
\text { Objetivo: conhecer os motivos } \\
\text { de recusa para doação de } \\
\text { órgãos. }\end{array}$ & $\begin{array}{l}\text { Constatados dez motivos de recusa considerados } \\
\text { pelos familiares, dentre eles, a crença religiosa. } \\
\text { Foi desvelado que a crença em Deus alimenta a } \\
\text { esperança da família de que um milagre possa } \\
\text { acontecer na recuperação de enfermos. Destaca } \\
\text { que as crenças culturais, mais do que as religiosas, } \\
\text { se opõem à doação, visto que as religiões Católica } \\
\text { Romana, Budista, Hindu, Muçulmana e Protestante } \\
\text { são favoráveis à doação, classificando-a como um } \\
\text { ato de generosidade. }\end{array}$ \\
\hline $\begin{array}{l}\text { Wang, } \\
\text { Wang, } \\
2010.27\end{array}$ & $\begin{array}{l}\text { Estudo de revisão da literatura } \\
\text { Área: Medicina } \\
\text { Objetivo: analisar a questão do } \\
\text { consentimento esclarecido sobre } \\
\text { a doação de órgãos, à luz da } \\
\text { ética confucionista, de presos } \\
\text { chineses condenados à morte } \\
\text { por crimes hediondos. }\end{array}$ & $\begin{array}{l}\text { Detectados casos em que os prisioneiros e suas } \\
\text { famílias consentiram em doar os órgãos após suas } \\
\text { execuções. Destaca que Confúcio considera que a } \\
\text { doação deve ser apreciada como um ato } \\
\text { moralmente louvável do prisioneiro que está } \\
\text { disposto a fazer um esforço final para arrepender- } \\
\text { se e corrigir sua má conduta. Porém, os chineses } \\
\text { consideram bom manter o corpo do membro da } \\
\text { família falecido intacto porque, do ponto de vista } \\
\text { de Confúcio, o corpo recebido de seus pais e } \\
\text { antepassados deve manter-se fiel à sua origem. }\end{array}$ \\
\hline
\end{tabular}

Quadro 1: Síntese dos artigos publicados no período de 1995 a 2010

\section{DISCUSSÃO}

Constatou-se que, no Brasil, existem poucos estudos que relacionam a crença religiosa e a doação e transplante de órgãos; paradoxalmente, este é um país de grande misticismo, com uma alta variedade de cultos e doutrinas religiosas. ${ }^{10} \mathrm{E}$, ainda que grande parte da literatura estudada seja de origem europeia, americana ou latina, e que há interessante correlação entre as crenças culturais e/ ou religiosas e a medicina estudos sinalizam que, atualmente, existem poucos dados na literatura biomédica sobre 0 assunto. ${ }^{14}$

Vários estudos ${ }^{10-12}, 19,22,23$ afirmam que nenhuma religião proíbe a doação de órgãos, ainda que alguns autores destaquem que existem, entre alguns líderes religiosos, desinformação e contradições ligadas ao assunto. Neste enfoque, é ressaltado o conhecimento insuficiente do conceito de morte encefálica. ${ }^{18}$ Mesmo assim, é sinalizado que os líderes religiosos entendem que a religião deve acompanhar os avanços da medicina. ${ }^{11}$

Há, pois, uma grande diversidade de entendimento das religiões acerca do momento de morte, embora o senso comum seja relacionar a morte física e ou o desligamento espiritual com o momento da parada dos batimentos cardíacos. ${ }^{10},{ }^{13}$ Os israelitas não permitem a retirada do coração por considerá-lo sinal de vida. ${ }^{10} \mathrm{Um}$ 


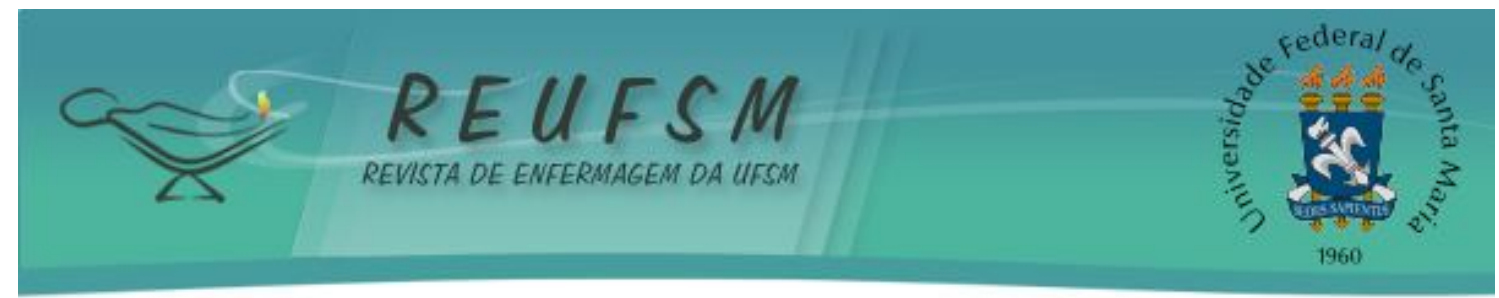

contraponto importante à não-doação é que, na maioria das culturas, corpo e alma estão interligados. Grande parte dos estudos mostra a crença de que a remoção de órgãos pode trazer malefícios à alma. O corpo, na cultura asiática, deve ser perfeito; se faltar alguma de suas partes, a alma torna-se infeliz. ${ }^{9}$ A retirada de órgãos pode ocasionar interferência negativa no desligamento do espírito do corpo. ${ }^{10}$ No budismo, remover órgãos é visto como perturbador da unidade integral de corpo e espírito, acarretando dor ao espírito e interferindo num renascimento bem-sucedido. ${ }^{13-14}$ Para 0 Taoísmo, corpo e natureza são alinhados, e retirar órgãos pode perturbar este equilíbrio. No Islamismo, o corpo é inviolável. Algumas culturas derivadas da doutrina budista, o xintoísmo e taoísmo não permitem a remoção de vísceras, não por não permitir a doação, mas porque seus rituais com o corpo após a morte impede tal prática. ${ }^{22}$ Embora o confucionismo considere louvável a atitude de doar órgãos, com base na cultura religiosa, os chineses consideram que o corpo deve ser mantido intacto para manter-se fiel ao recebido de seus pais e antepassados. ${ }^{27}$ Dentre outros fatores contraditórios à doação a crença no conceito de sepultamento do corpo inteiro, sem mutilação, mantém boa relação entre os mortos e que remover órgãos compromete rituais de sepultamento. ${ }^{18}$

0 ato de doar órgãos, também, é visto como forma proativa de manifestar 0 altruísmo religioso, e a decisão de doar estaria alinhada com convicções espirituais. ${ }^{15}$ De outro modo, 0 ato de doar tem uma conotação mística e religiosa no sentido de conceder a continuidade de vida a alguém. ${ }^{17} \mathrm{~J}$ á, a lei islâmica permite renunciar à proibição de não violar o corpo, vivo ou morto, desde que seja para salvar vidas. Por fim, no sikhismo, a vida continua na alma, e é importante doar para ajudar quem precisa de um órgão para continuar vivendo. ${ }^{19}$

Dois estudos ${ }^{11,16}$ concluiram que não existe influência significativa da religião em relação à opinião de fiéis sobre o assunto, o que corrobora com as conclusões de outro estudo $^{12}$ ef etivado na população asiática, no qual cultura e religião têm um papel menos proibitivo quanto à doação do que o esperado pelos pesquisadores inicialmente.

A religião aparece como aconselhador no processo de tomada de decisão, tornando-se mais tranquilo ser favorável à doação quando há apoio por parte da crença religiosa ${ }^{17}$, ou ainda, quando se conhece se a religião praticada é ou não a favor da doação. ${ }^{25}$ É salientado, também, que as pessoas que menos frequentam os eventos religiosos, são mais favoráveis à doação do que aquelas que praticam à risca os ensinamentos. ${ }^{14}$ Entre os chilenos, a religião é motivo de negação ao consentimento em 10 $\%$ dos casos de potenciais doadores. ${ }^{24}$

Faz-se necessário entender a articulação entre cultura e religião. Na sociedade japonesa, existe forte barreira cultural ao transplante de órgãos. ${ }^{9}$ É destacado o conflito entre a cultura europeia e a cultura japonesa. ${ }^{9} \mathrm{Na}$ cultura chinesa, há intensa influência cultural à não-doação devido à forma como lidam com o corpo morto. ${ }^{14} \mathrm{O}$ Alcorão, escrita sagrada do islamismo, menciona que qualquer tratamento para manter a saúde é aceito; nesse caso, a doação e o transplante de órgãos não fogem è regra, e a baixa taxa de doadores neste segmento deve-se ao respeito ao corpo que existe na cultura islâmica. ${ }^{20}$ Considerando-se a permanência da religião e da cultura e a lentidão que se processa as mudanças nestes campos, pode-se dizer que tanto uma como a outra impactam negativamente nas taxas de doadores. ${ }^{21}$ Mas, as crenças culturais, mais do que as religiosas, opõem-se à doação, visto que a maioria das religiões é favorável, classificando a doação como um ato de generosidade. ${ }^{26}$ 


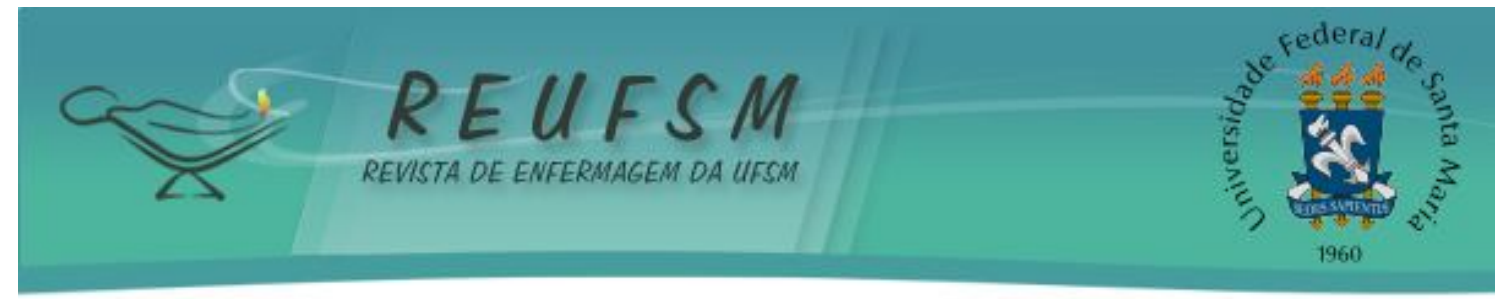

CONCLUSÃO

A pesquisa mostrou que nenhuma religião é de modo absoluto contrária à doação. Nas religiões, baseadas ou não na existência de Deus - no caso do budismo -, a morte está relacionada ao binômio corpo e espírito, onde o corpo é matéria e tem fim, e o espírito continua em outras esferas de "vida". O fator contraditório justifica-se, visto que as crenças religiosas possuem uma série de rituais com o corpo após a morte. Algumas não aceitam pacificamente o conceito de morte encefálica, relacionando a morte à parada dos batimentos cardíacos e da respiração. A ideia de mutilação do corpo está presente. É comum em muitas crenças relacionar agressões ao corpo com traumas para a alma e problemas para o destino espiritual adequado.

É essencial, por parte da equipe de saúde, um nível mínimo de entendimento da diversidade cultural e religiosa, condição esta necessária para a prestação de cuidados que são culturalmente sensíveis. Para a enfermagem, com a conquista de espaço profissional no processo de captar órgãos, e a consciência da necessidade da visão holística na assistência, o conhecimento de fatores culturais que norteiam a conduta em saúde das pessoas torna-se importantíssimo para uma abordagem assertiva no momento de acolher as decisões de pacientes e suas famílias.

As limitações deste estudo referem-se à ausência de publicações que articulem cultura e religião, principalmente, no Brasil. Neste sentido, dos artigos analisados e escritos por brasileiros, os sujeitos de pesquisa foram familiares de doadores ou potenciais doadores, estudantes e líderes religiosos. Inexistem dados estatísticos brasileiros que componham um panorama da possível influência cultura/religião na doação de órgãos e tecidos. Assim, torna-se pertinente a realização de pesquisas que explicitem melhor a questão em seus múltiplos aspectos.

\section{REFERÊNCIAS}

1. Leite RCC. Transplantes de órgãos e tecidos e os direitos da personalidade. 3ạ ed. São Paulo: Juarez de Oliveira; 2000.

2. Bousso RS. O processo de decisão familiar na doação de órgãos do filho: uma teoria substantiva. Texto \& contexto enferm. 2008; 17 (1): 45-54.

3. Alcântara L. Lei da vida: doação de órgãos. 1ạ ed. Brasília: Senado Federal; 1998.

4. Sabini TL, Vargas MAO, Amaral V. Comissão intra-hospitalar de doação de órgãos e tecidos para transplante: vivências de um hospital de pronto socorro em trauma. Rev paul enferm. 2007; 26 (3): 190-200.

5. Goldim J R. Consentimento presumido para doação de órgãos: a situação brasileira atual [página na internet]. Porto Alegre; 2005. [acesso em 2009 Mar 28]. Disponível em: www. bioetica. ufrgs. br.

6. Potter PA, Perry AG. Fundamentos de Enfermagem. 6a ed. Rio de Janeiro: Elsevier; 2005.

7. Kung H. Por que ainda ser cristão hoj e? 1a ed. Campinas: Verus; 2004.

8. Vargas MAO, Ramos FRS. A morte cerebral como o presente para a vida: explorando práticas culturais contemporâneas. Texto \& contexto enferm. 2006; 15 (1): 137-45.

9. Morioka M. Bioethics and Japanese Culture. Eubios Journal of Asian and International Bioethics. 1995; 5: 87-90. 


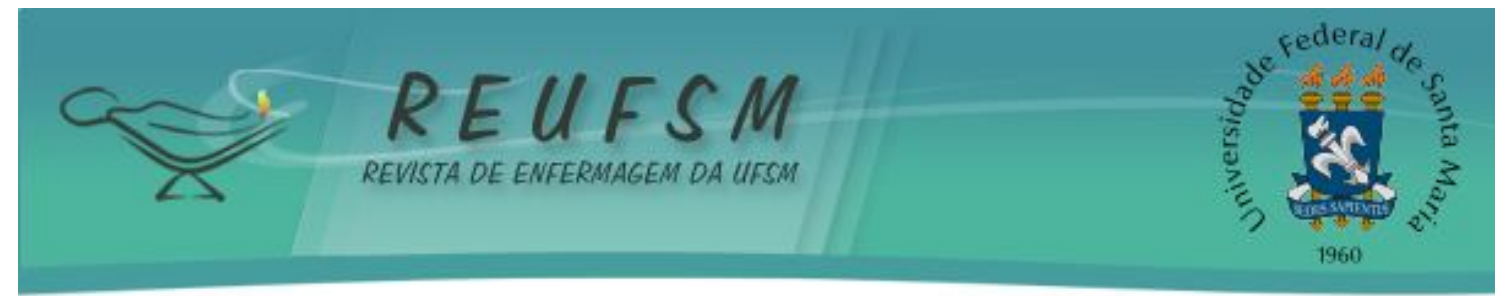

10. Knauth D. Um estudo das representações religiosas sobre doações de órgãos e sangue e influência da definição do momento da morte [página na Internet]. Porto Alegre; 1997 [acesso em 2009 Mar 28]. Disponível em: www. bioetica. ufrgs.br.

11. Gualandro DM, Vilarino FL, Soccol FM, Almeida JRC, Neves MAT. A. Nova Lei dos Transplantes: a percepção de populares e de religiosos. Arq méd ABC. 1997; 1 (2): 15-21.

12. Randhawa G. An exploratory study examining the influence of religion on attitudes towards organ donation among the Asian population in Luton, UK. Nephrol Dial Transplant. 1998; 13: 1949-54.

13. Pessini L. A eutanásia na visão das grandes religiões mundiais. Mundo saúde. 1999; 23: 317-31.

14. Lam WA, Mccullough LB. Influence of religious and spiritual values on the willingness of Chinese-Americans to donate organs for transplantation. Clin Transplantat. 2000; 14 (5): 449-56.

15. Dixon DJ, Abbey SE. Religious altruism and organ donation. Psychosomatics. 2000; 41 (5): 407-11.

16. Bendassoli PF. Percepção do Corpo, Medo da Morte, Religião e Doação de Órgãos. Psicol Reflex Crít. 2001; 14 (1): 225-40.

17. Sadala MLA. A experiência de doar órgãos na visão de familiares de doadores. J bras nefrol. 2001; 23 (3): 143-51.

18. West R, Burr G. Why families deny consent to organ donation. Aust Crit Care. 2002; 15 (1):27-32.

19. Howitt R [página na Internet]. Inglaterra; 2003 [acesso em 2010 Julho 03]. Disponível em: www. organdonation.nhs. uk

20. Akrami SM, Osati Z, Zahedi F, Raza M. Brain Death: Recent Ethical and Religious Considerations in Iran. Transplantation Proceedings. 2004; 36: 2883-7.

21. Blok GA. Approaching donor families: culture, religion and ethnicity. Current Opinion in Organ Transplantation. 2006; 11: 123-9.

22. Velez EV. Donación de órganos, una perspectiva antropológica. Rev Soc Esp Enferm Nefrol. 2007; 10 (3): 19-25.

23 Bruzzone P. Religious Aspects of Organ Transplantation. Transplantation Proceedings. 2008; 40 (1): 1064-7.

24. Solar SP, Ovalle AR, Simian MEM, Escobar J H, Beca J PI. Tres factores que influyen en la actitud de las personas ante la donación de órganos. Rev Chil Cir. 2008; 60: 262-7.

25. Rios A, Alarcón LM, Sanches J , J arvis N, Garcia J M, Parrilla P, Ramirez P. The quest for favourable subgroups to encourage living kidney donation in Spain. An attitudinal study among British and Irish citizens resident in southeastern Spain. Nephrol Dial Transplant. 2008; 23: 1720-7.

26. Moraes EL, Massarollo MCKB. Recusa de doação de órgãos e tecidos para transplante relatados por familiares de potenciais doadores. Acta paul enferm. 2009; 22: 131-5.

27. Wang $M$, Wang $X$. Organ donation by capital prisoners in China reflections in Confucian ethics. J ournal of Medicine and Philosophy. 2010; 35: 197-212. 


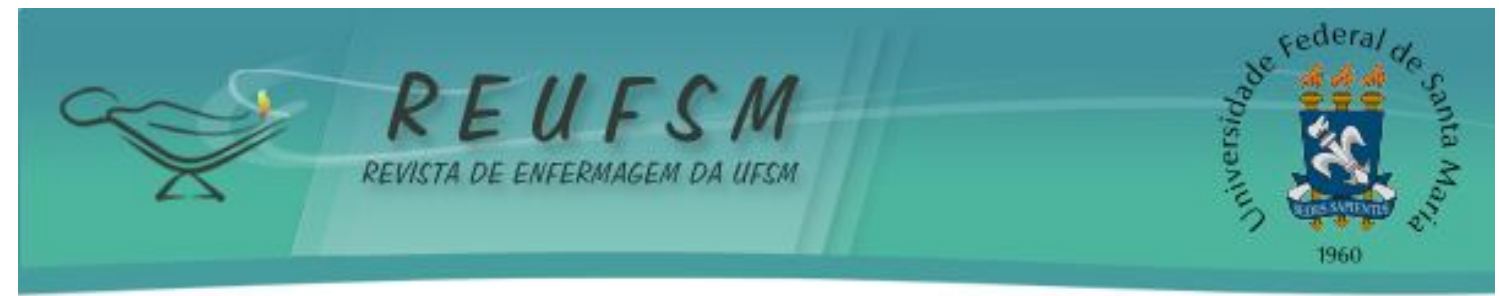

Data de recebimento: 04/04/ 2011

Data de aceite: 06/09/2011

Contato com autora responsável: Mara Ambrosina de Oliveira Vargas

Endereço: Departamento de Enfermagem - Centro de Ciências da Saúde UFSC. Campus Universitário, sn. Bairro Trindade.

CEP: 88040-970.

E-mail: mara@ccs.ufsc.br 